UDC: 595.763 .2 .768

\title{
ECOLOGICAL AND ZOOGEOGRAPHICAL GROUPS OF ROVE BEETLES (STAPHYLINIDAE, COLEOPTERA, INSECTA) OF SUBALPINE BELT OF NORTHEASTERN MACROSLOPE OF UKRAINIAN CARPATHIANS
}

\author{
M. P. Lutska \\ Vasyl Stephanyk Precarpathian National University \\ 22, Galitska St., Ivano-Frankivsk 76000, Ukraine \\ e-mail: mariana.93.if@ukr.net
}

Lutska M. P. Ecological and zoogeographical groups of rove beetles (Staphylinidae, Coleoptera, Insecta) of Subalpine Belt of Northeastern macroslope of Ukrainian Carpathians. Studia Biologica, 2019: 13(1); 107-116 • DOI: https://doi.org/10.30970/sbi.1301.584

The ecological and zoogeographical structure of rove beetles was analyzed in the biotope of crooked forest Pinus mugo Turra, 1764 of the Subalpine Belt of the NorthEastern macro-slope of the Ukrainian Carpathians. As a result of conducted study, the representatives of 24 species belonging to 19 genera and 10 subfamilies were detected within the biotope. The subfamilies Staphylinidae (25\%) which is characterized by the presence of representatives of 5 genera. The representatives of Ocypus genera (3 species), Atrecus, Emus, Philonthus, Quedius were identified within the studied biotope. Each of them was presented by the individuals of one species. A slightly lower number of identified species is typical for the Tachyporinae subfamily -5 species belonging to the three genera Lordithon (1 species), Tachinus (2 species), Tachyporus (2 species). Subfamilies Omaliinae and Oxytelinae are presented by the genera Pycnoglypta, Omaliinae, Olophrum and Oxytelus, Anotylus, Deleaster. A part of subfamilies characterized by the presence of the representatives of only one species equals $50 \%$. This group of subfamilies includes: Oxyporinae, Paederinae, Pselaphinae, Steninae, Xantholininae, Olistaerinae that are represented by one species.

According to Margaleff and Mennicin a display number of the species abundance are rather high (4.19 and 1.60,). This aspect indicates a small number of eudominant and dominant species. Simpson index (0.09) indicates a significant diversity of representatives of subdomains and retsendents. The Berger Parker index is low (0.18) that indicates a minor quantity of representatives of the most numerous species - Pycnoglypta lurida (Gyllenhal, 1813).

(c) 2019 M. P. Lutska. Published by the Ivan Franko National University of Lviv on behalf of Біологічні Студії / Studia Biologica. This is an Open Access article distributed under the terms of the Creative Commons Attribution License (http://www.budapestopenaccessinitiative.org/ and Creative Commons Attribution 4.0 License), which permits unrestricted reuse, distribution, and reproduction in any medium, provided the original work is properly cited.

ISSN 1996-4536 (print) • ISSN 2311-0783 (on-line) • Біологічні Студії / Studia Biologica • 2019 • Том 13/№1 • C. 107-116 
Staphylinidae group is characterized by the presence of representatives of four classes of domination (eudominants, dominants, subdominants and recedants) within the biotope of mountainous pines. The representatives of eudominants (Deleaster dichrous (Gravenhorst, 1802), Olophrum rotundicolle Sahlberg,1830 and Pycnoglypta lurida Gyll., 1813) and dominants (Emus hirtus Linnaeus, 1758, Tachinus elongatus Gyllenhal., 1810) groups form the centerpiece of the researched group.

The groups of subdominants and recedants are characterized by a presence of representatives of 13 species and 6 species, respectively.

As a result of analysis of ecological and morphological groups, it was revealed that the largest number of species belongs to a group of epibionts $(58.34 \%)$, borers $(28.14 \%)$, cryptobionts (12.51\%).

A vast majority of species detected by trophic specialization are the predators (65\%). A slightly smaller number of species belongs to a group of micsophages that combine peculiarities of both nutrition predators and mycetophages or saprophages.

According to area analysis, most of the detected species belong to the Holarctic and Palaearctic types of the zoogeographical zones.

Keywords: Staphylinidae, ecological and zoogeogaphical groups, life strategies, Ukrainian Carpathians

\section{INTRODUCTION}

Staphylinidae is one of the most numerous solid-winged families on our planet. There are 83 thousand species of rove beetles belonging to 32 subfamilies of fauna. The representatives of this family were found in all types of the terrestrial ecosystems. They are common in the steppes, gardens, fields, meadows near the reservoirs, however, there are no water species among the representatives of this family. The representatives of Staphylinidae play a significant role in forest ecosystems where they rank second in numbers. The beetles-predators are widespread under the bark of trees, stones, forest litter, moss, silage packs, animal corpses, or under organic substances that are at different stages of the decomposition. The rove beetles are especially numerous and diverse in the forest litter [2, 7, 9, 12].

One of the most important directions of modern ecology is the allocation of life forms or morphological ecotypes. Their analysis has become an applied method used by specialists in systematic groups of both vertebrate and invertebrate animals. A system of life forms is used for the analysis of habitat characteristics [5].

\section{MATERIALS AND METHODS}

Studying the groups of rove beetle in the biotope of the pine-mountainous northeastern macro-slope of the Ukrainian Carpathians occurred during a spring-summer period of 2017-2018. A research took place near the peak of Dovbushanka in the biotope of the curvilinear Pinus mugo Turra, 1764 at an altitude of 1600 meters above sea level $48^{\circ} 42^{\prime} 50 ; 24^{\circ} 37^{\prime} 44$.

The material was collected using Berber's traps. On the territory of the studied habitat, 10 soil Berber traps were set $(0.5$ I plastic cups and $65 \mathrm{~mm}$ diameter hole diameter). Traps were located after $1 \mathrm{~m}$ and checked every 7 days. $4 \%$ solution of formalin was used as a fixator.

ISSN 1996-4536 (print) • ISSN 2311-0783 (on-line) • Біологічні Студії / Studia Biologica • 2019 • Том 13/№1 • С. 107-116 
All collected material was remained at the Zoological Museum of the Faculty of Natural Sciences of the Precarpathian National University named after V. Stefanyk. The species identification was carried according to the indicators of Bei-Bienka and Lucid keys [1, 15]. A division of species into ecological groups was done according to the method of V. Kashcheev [5]. Determination of a degree of dominance was carried out according to the method of $\mathrm{H}$. Engelmann [3] For zoogeographical analysis and nomenclature of the identified range of species, a technique of K. Gorodkov was applied [4]. The species analysis and their distribution were conducted according to the Catalog of Palaearctic Coleoptera [6].

\section{RESULTS AND DISCUSSION}

A group of rove beetles in the biotope of the pine mountains of the north-eastern macro-slope of the Ukrainian Carpathians is characterized by the presence of representatives of 24 species that belong to 19 genera and 10 subfamilies. The highest level of the abundance of species is inherent to the subfamily Staphylininae characterized by the presence of the representatives of 5 genera. The representatives of Ocypus ( 3 species) genera, Atrecus, Emus, Philonthus, Quedius were identified within the studied biotope. Each of them was presented by individuals of one species. A slightly lower number of identified species was typical for the Tachyporinae subfamily -5 species belonging to three genera Lordithon (1 species), Tachinus (2 species), Tachyporus (2 species). Subfamilies Omaliinae and Oxytelinae are represented by the genera Pycnoglypta, Omaliinae, Olophrum and Oxytelus, Anotylus, Deleaster. Each of these families has only one species. Subfamilies Oxyporinae (Oxyporus), Paederinae (Paederus), Pselaphinae (Pselaphus), Steninae (Stenus), Xantholininae (Xantholinus), Olistaerinae (Olistaerus) are represented by the individuals of only one species.

A display numbers of the species abundance according to Margaleff and Mennicin are rather high (4.19 and 1.60). This aspect indicates a small number of eudominant and dominant species. Simpson index (0.09) indicates a significant diversity of representatives of subdomains and retsendents. Berger Parker index is low (0.18) that indicates a minor quantity of the representatives of the most numerous species - Pycnoglypta lurida (Gyll, 1813). A structure of domination in the group of beetles-predators within the biotope of the pine-mountainous north-eastern macro-slope of the Ukrainian Carpathians is characterized by presence of the representatives of four classes of domination (eudominant, dominant, subdominant, and retsedents). A core of this group consists of representatives of the eudominant class (Deleaster dichrous (Grav., 1802) and Pycnoglypta lurida (Gyll, 1813), which accounts for $16.46 \%$ and $17.69 \%$ in the group respectively), as well as the dominant (Emus hirtus Linnaeus, 1758, Olophrum rotundicolle Sahl., 1830, Tachinus elongates Gyll.1810). The sub-domains and retsedents classes account for 50 and $29 \%$, respectively.

An important aspect for describing the relationship between insects and the habitat is the definition of life forms of their imago, makes it possible to analyze in detail the features of the biotopes. A concept of "eco-morphological" form in a broad sense reflects the morphological adaptation of organisms that ensures exploitation of their ecological niches [5].

The representatives of fourteen ecological-morphological groups that belong to three classes: epibionts, boreholes and cryptobionts are inherent for the biotope of the Pinus mugo Turra, 1764 north-eastern macro-slope of the Ukrainian Carpathians.

ISSN 1996-4536 (print) • ISSN 2311-0783 (on-line) • Біологічні Студії / Studia Biologica • 2019 • Том 13/№1 • С. 107-116 
Table 1. Total number and percentage of discovered species of rove beetles within Pinus mugo Turra 1774 biotope of the northeastern macro-slope of the Ukrainian Carpathians

Таблиця 1. Загальна кількість особин і відсоткова частка виявлених видів жуків-хижаків у межах біотопу Pinus mugo Turra 1774 північно-східного макросхилу Українських Карпат

\begin{tabular}{|c|c|c|c|c|}
\hline Species & 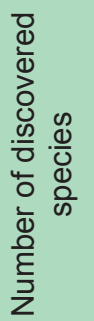 & $\%$ & 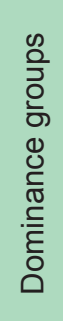 & Subfamily \\
\hline P. lurida Gyllenhal,1813 & 43 & 17.7 & $E$ & Omaliinae \\
\hline D. dichrous Gravenhorst,1802 & 40 & 16.5 & $E$ & Oxytelinae \\
\hline E. hirtus Linnaeus, 1758 & 20 & 8.23 & $\mathrm{D}$ & Staphylininae \\
\hline O. rotundicolle Sahlberg, 1830 & 20 & 8.23 & $D$ & Omaliinae \\
\hline O. compressus Marsham,1802 & 15 & 6.17 & $\mathrm{D}$ & Staphylininae \\
\hline T. elongates Gyllenhal, 1810 & 15 & 6.17 & $\mathrm{D}$ & Tachyporinae \\
\hline A. longiceps Fauvel, 1873 & 10 & 4.11 & SD & Staphylininae \\
\hline Q. transsylvanicus Weise, 1875 & 10 & 4.11 & SD & Staphylininae \\
\hline O. caesum Gravenhorst, 1806 & 10 & 4.11 & SD & Omaliinae \\
\hline L. trinotatus W.F. Erichson, 1839 & 10 & 4.11 & SD & Tachyporinae \\
\hline M. nitens (Schrank, 1781) & 8 & 3.29 & SD & Staphylininae \\
\hline T. rufipes (Linnaeus, 1758) & 7 & 2.88 & SD & Tachyporinae \\
\hline P. rubrothoracicus (Goese,1808) & 5 & 2.06 & SD & Paederinae \\
\hline X. glabratus Gravenhorst, 1802 & 5 & 2.06 & SD & Xantholininae \\
\hline Ph. nitidus (Fabricius, 1787) & 5 & 2.06 & SD & Staphylininae \\
\hline O. olens O.F. Muller 1764 & 3 & 1.23 & SD & Staphylininae \\
\hline P. heiser & 3 & 1.23 & SD & Pselaphinae \\
\hline Q. paradisianus (O. Heer, 1839) & 3 & 1.23 & SD & Staphylininae \\
\hline A. tetracarinatus (Block, 1799) & 2 & 0.82 & $\mathrm{R}$ & Staphylininae \\
\hline Ph. decorus (Gravenhorst, 1802) & 2 & 0.82 & $\mathrm{R}$ & Staphylininae \\
\hline O. rufus rufus (Linnaeus, 1758) & 2 & 0.82 & $\mathrm{R}$ & Oxyporinae \\
\hline A. rugosus (Sabricius, 1775) & 2 & 0.82 & $\mathrm{R}$ & Oxytelinae \\
\hline S. comma LeConte, 1863 & 2 & 0.82 & $\mathrm{R}$ & Steninae \\
\hline O. substriatus (Paykul, 1790) & 1 & 0.41 & $\mathrm{R}$ & Olistaerinae \\
\hline $\mathrm{D}(\mathrm{Mg})$ & & 4.19 & & \\
\hline $\mathrm{D}(\mathrm{Mn})$ & & 1.60 & & \\
\hline D & & 0.09 & & \\
\hline $\mathrm{D}(\mathrm{BP})$ & & 0.18 & & \\
\hline
\end{tabular}

Coments: $\quad \mathrm{D}(\mathrm{Mg})-$ Margaleff index; $\mathrm{D}(\mathrm{Mn})$ index of Menginika; $\mathrm{D}$ - Simpson index; $\mathrm{D}(\mathrm{BP})$ is the BergerParker index

Примітки: D (Mg) - індекс Маргалефра, D (Mn) - індекс Менхініка, D - індекс Сімпсона, D (BP) - індекс Бергера-Паркера

ISSN 1996-4536 (print) • ISSN 2311-0783 (on-line) • Біологічні Студії / Studia Biologica • 2019 • Том 13/№1 • C. 107-116 
Fig. 1. A structure of the domination of groups of beetles-predators in the biotope of the pine mountain subalpine zone of the northeastern macro slope of the Ukrainian Carpathians

Рис. 1. Структура домінування угруповань жуків-хижаків у біотопі сосни гірської субальпійського поясу північно-східного макросхилу Українських Карпат

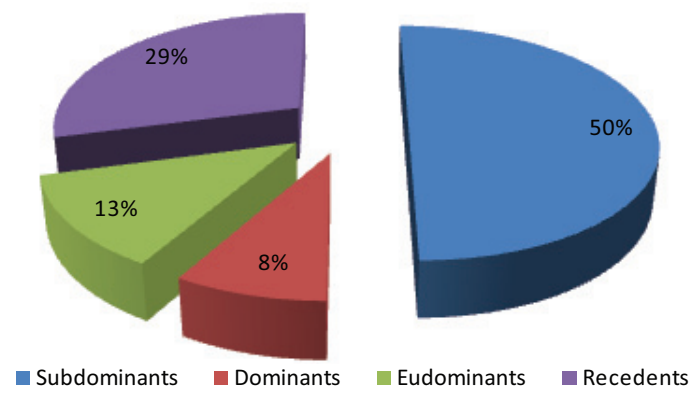

The biggest role in this biotope belongs to the class of epibionts (58.34\%) represented by individuals of 14 species forming a subclass of running. The most numerous group within this subclass is stratobiont (9 species $37.5 \%$ ). The representatives of the stratohortobionts group are characterized by a lower level of species diversity (this group includes the representatives of 3 species accounting for $12.5 \%$ ). The representatives of epibiont groups of running necrobionts and coprobionts are the least numerous within this habitat. The representatives of the species Emus hirtus L., 1758 that are often found in various groups of plant and animal remnants and less common in forest litter [9]. Epibionti running coprobionts include the representatives of the species Anotylus tetracarinathus Block 1799 common in horse and cow serum [12].

A significant proportion of species of beetles-predators belongs to a class of drill bits represented by 8 species. They amount to $28.14 \%$ of the total number and reffere to running and swallowing subclasses. The most numerous group is the piercing boreholes stratobionts including the representatives of three species that makes up $12.5 \%$ of the total number. The members of the species Oxyporus rufus rufus L., 1758 belong to a group of the mycetobionts that amount $4.17 \%$. The individuals of this species are often found in the fleshy bodies of plate and tubular fungi in which the strokes from the inside of the cap are being gnawed [11].

In comparison to the previous group, there is a slightly smaller percentage $12.51 \%$ of the number of the cryptobionts in the biotope of the pine mountain subalpine zone of the northeastern macro-slope of the Ukrainian Carpathians. This class includes the exponents of two groups. The group of cryptobionts running stratobion includes species of Atrecus longiceps Fau., 1873 and Xantholinus glabrathus Grav., 1802. The group of cryptobionts of the nurses of subcriminals includes members of the species Lordithon trinotatus (Erich. 1839). (Table 2, Fig. 2).

As a result of analysis of the trophic specialization of the identified species Staphylinidae, it has been established that the vast majority belongs to a group of predators. These are the representatives of 15 identified species that make up $65 \%$. Such species as oligophagous and polyphages are found among them who are effective regulators of the number of agricultural pests. Much of the identified species belong to a group of the myxophages. Its representatives are divided into mycetofagus predators making up $16.7 \%$ of the detected species and predators-saprophages $-8.3 \%$. The representatives of the subgroup of the predator saprophages include Ocypus olens (O.F. Mull., 1764). They are specialised predators hunting for Helix aspersa Mullur., 1774, Helix pomatia Linnaeus, 1758, and in some other cases they are able to feed on the organic matter, present in different waste. The representatives of the species

ISSN 1996-4536 (print) • ISSN 2311-0783 (on-line) • Біологічні Студії / Studia Biologica • 2019 • Том 13/№1 • С. 107-116 
Lordithon trinotatus Erich., 1839 espouse being a predator-polyphagus and optional saprophagia. A group of predators-mycetofag includes the members of Omalium caesum Grav., 1806 species [9].

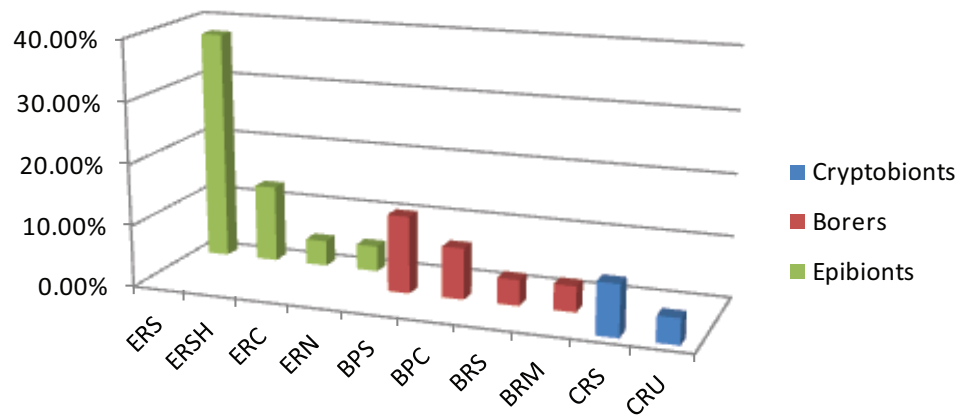

Fig. 2. A structure of morphological and ecological classes of the groups of beetles-predators of the habitat of the pine forest of the mountain subalpine zone of the northeastern macro-slope of the Ukrainian Carpathians

Coments: ERS - epibiotics running stratobiots; ERSH - Epibionts running stratochortoobionts; ERC - epibionts running coprobionts; ERN - epibionts running necrobionts; BPS - borehole plunging stratobionts; BRC - boreholes running coprobionts; BRS - boreholes running subcortex; BPM boreholes for picking micetobionts; CRS - cryptobionts running stratobiots; CRU - cryptobionts running undercurrent

Рис. 2. Структура морфолого-екологічних класів угруповань жуків-хижаків біотопу сосни гірської субальпійського поясу північно-східного макросхилу Українських Карпат

Примітки: ERS - епібіонти бігаючі стратобіонти; ERSH - епібіонти бігаючі стратохортобіонти; ERC - епібіонти бігаючі копробіонти; ERN - епібіонти бігаючі некробіонти; BPS - свердловинники риючі стратобіонти; BRC - свердловинники бігаючі копробіонти; BRS - свердловинники бігаючі підкірники; BPM - свердловинники риючі міцетобіонти; CRS - криптобіонти бігаючі стратобіонти; CRU - криптобіонти бігаючі підкірники

The lowest level of numbers is typical for representatives of groups of the saprophages, nematophages and mycetophages. Each of these groups includes one species Anotylus tetracarinathus (Block, 1799) and Oxytelus rugosus Fab., 1775 Oxyporus rufus rufus L., 1758, respectively. (Table 2, Fig. 3).

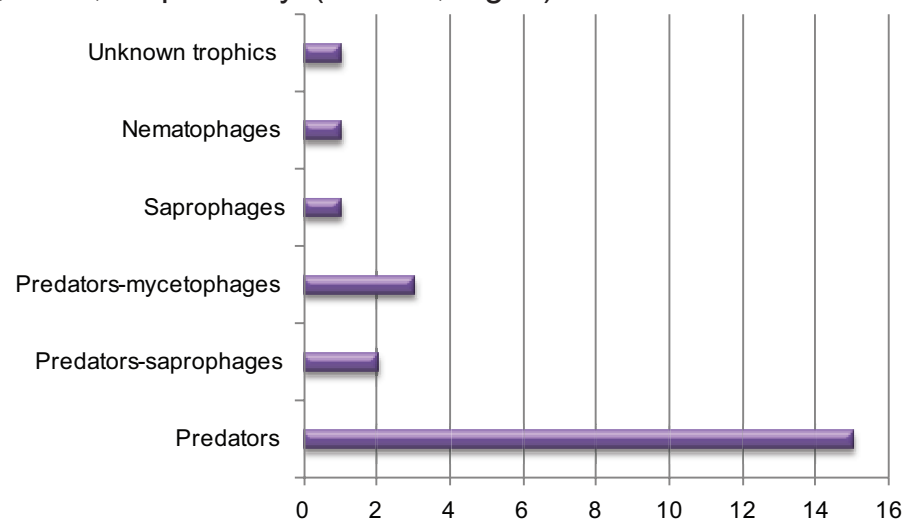

Fig. 3. A trophic structure of a group of short-necked beetles in the biotope of the pine mountain subalpine zone of the northeastern macro-slope of the Ukrainian Carpathians

Рис. 3. Трофічна структура угруповання коротконадкрилих жуків у біотопі сосни гірської субальпійського поясу північно-східного макросхилу Українських Карпат 
Table 2. Ecological structure of groups of beetles-predators biotope of pine mountain subalpine zone of the northeastern macro-slope of the Ukrainian Carpathians

Таблиця 2. Екологічна структура угруповань жуків-хижаків біотопу сосни гірської субальпійського поясу північно-східного макросхилу Українських Карат

\begin{tabular}{|c|c|c|c|c|c|c|}
\hline$\underset{w / 0}{N}$ & Species & 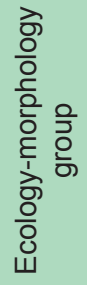 & $\begin{array}{l}\frac{\pi}{\pi} \\
\frac{\pi}{0} \\
\frac{\pi}{1}\end{array}$ & 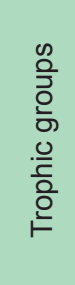 & 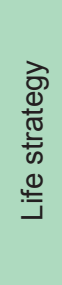 & 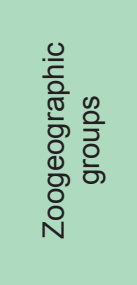 \\
\hline 1. & P. lurida & ER & S & Ukn. & CS & Hol. \\
\hline 2. & O. rotundicolle & ER & $S$ & P. & $S$ & E-Sib \\
\hline 3. & O. caesum & ER & $\mathrm{s}$ & P-M & S & Pal \\
\hline 4. & P. heiser & ER & $\mathrm{s}$ & $\mathrm{P}$ & $\mathrm{R}$ & Hol. \\
\hline 5. & A. tetracarinatus & ER & C & $S$ & SR & Hol. \\
\hline 6. & D. dichrous & ER & $S$ & $P$ & SR & Hol. \\
\hline 7. & A. rugosus & ER & $S$ & $\mathrm{~N}$ & $\mathrm{R}$ & Hol. \\
\hline 8. & A. longiceps & $\mathrm{CN}$ & $S$ & $P$ & $\mathrm{R}$ & Hol. \\
\hline 9. & E. hirtus & ER & $\mathrm{N}$ & $\mathrm{P}$ & C & E. \\
\hline 10. & O. compressus & $\mathrm{BR}$ & $S$ & $\mathrm{P}$ & CR & $E$ \\
\hline 11. & O. nitens & $\mathrm{BR}$ & $S$ & $\mathrm{P}$ & $C$ & $\mathrm{Hol}$ \\
\hline 12. & O. olens & BR & $S$ & $P$ & C & Hol. \\
\hline 13. & Ph. nitidus & $\mathrm{BR}$ & C & $P$ & $\mathrm{R}$ & $E$ \\
\hline 14. & Q. transylvanicus & BR & C & $\mathrm{P}$ & C & End \\
\hline 15. & O. rufus rufus & BR & M & P-M & SR & Pal \\
\hline 16. & P. rubrothoracicus & ER & $\mathrm{SH}$ & $\mathrm{P}$ & SR & West-Pal \\
\hline 17. & S. ater & ER & $\mathrm{SH}$ & $\mathrm{P}$ & SR & Pal \\
\hline 18. & L. trinotatus & $\mathrm{BR}$ & $S$ & P-S & CS & West-Pal \\
\hline 19. & T. elongatus & ER & $\mathrm{SH}$ & $\mathrm{P}$ & S & Hol. \\
\hline 20. & T. rufipes & ER & $S$ & P-M & SR & Пал \\
\hline 21. & T. hypnorum & ER & $S$ & $\mathrm{P}$ & $\mathrm{R}$ & West-Pal \\
\hline 22. & T. chrysomelinus & ER & $S$ & P-M & $\mathrm{R}$ & Hol. \\
\hline 23. & $X$. glabratus & BR & $\mathrm{SH}$ & $\mathrm{P}$ & $\mathrm{R}$ & $\mathrm{E}$ \\
\hline 24. & O. substriatus & BR & S & $\mathrm{P}$ & SR & $\mathrm{E}$ \\
\hline
\end{tabular}

As a part of the investigated group of Staphilinidae, the representatives of six types of life strategies (violent, patient, apologenta, violent-exploratory, violent-patient, and patient-exploratory) were identified. The largest number of species belongs to the patient exploratory ( 7 species) and the exploratory ( 7 species) groups that amount to $58.34 \%$ of the total number. In addition, there are individuals with violent type of life strategy in the studied biotope. This group includes the members of such species as Emus hirthus L., 1758, Ocypus nitens (Sch., 1781), Ocypus olens (O. F. Mull., 1764) and Quedius transsylvanicus L., 1758. The studied group is represented by three species: Olophrum rotundicolle (Sahl., 1830), Omalium caesum Grav. 1806, Tachinus elongatus Gyll., 1810. The smallest number of species belongs to the violent-exploratory group. These are the representatives Ocypus compressus (Marsh., 1802) of species (Table 2, Fig. 4).

ISSN 1996-4536 (print) • ISSN 2311-0783 (on-line) • Біологічні Студії / Studia Biologica • 2019 • Том 13/№1 • С. 107-116 


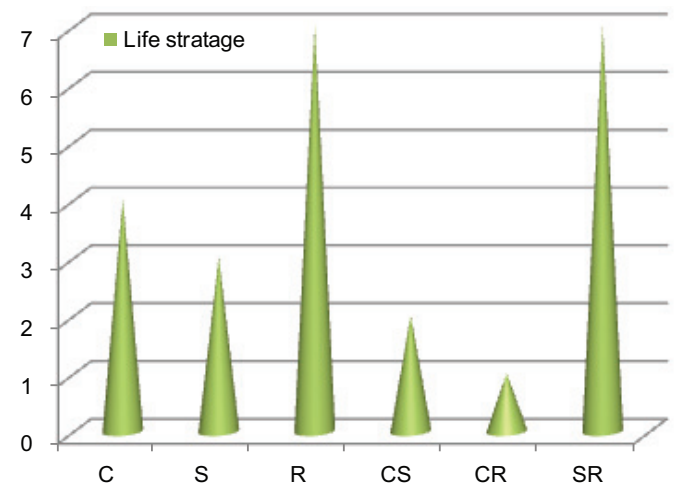

Fig. 4. A structure of life strategies of the beetle-predators in the biotope in the pine mountain subalpine zone of the northeastern macro-slope of the Ukrainian Carpathians

Coments: C - Violent; S - Patience; R - Exploratory; CS - Violent-Patient; CR - Violent-Explanatory; SR - Patient-Explanatory Types of Life Strategies

Рис. 4. Структура життєвих стратегій жуків-хижаків у біотопі сосни гірської субальпійського поясу північно-східного макросхилу Українських Карпат

Примітки: C - віолентний; S - патієнтний; R - експлерентний; CS - віолентно-патієнтний; CR віолентно-експлерентний; SR - патієнтно-експлерентний типи життєвих стратегій

According to conducted zoogeographical analysis, the Staphylinidae group in the biotope of the Pinus mugo T. 1764 in the subalpine zone of the northeastern macroslope of the Ukrainian Carpathians includes the representatives of 9 zoogeographical complexes covering the whole territory of the Palearctic. However, among the identified species there is one endemic species - Quedius transsylvanicus L. 1758. This species is characterized by low ecological valency and occurs in the highlands of the Ukrainian Carpathians. The individuals of this type are vulnerable, their number is constantly decreasing due to the intensive growth of the anthropogenic load [10].

The exponents of Pycnoglypta lurida Gyll., 1827, Anotylus tetracarinatus (Block, 1799), Deleaster dichrous (Grav., 1802), Oxytelus rugosus Fab.1775, Atrecus longiceps Fauv., 1873, Ocypus olens O.F. Mull.1764, Tachinus elongathus Gyll., 1810, Tachyporus chrysomelinus L., 1758 species are characterized by the presence of habitats, which, to a greater or lesser extent, cover the whole of the Holarctic. The representatives of the Ocypus nitens (Schrank, 1781) species are characterized by the presence of a secondary holarctic type of habitat.

A large number of species is characterized by the presence of a palaearctic type of range. They make up $29.17 \%$ of the total number of species. Among the representatives of this group there are species that occur throughout the Palearctic $(12.5 \%)$ - to this group include: Oxyporus rufus rufus L. 1758, Stenus comma LeConte 1863, Tachinus rufipes L., 1758. A group of species is found exclusively in the western part of Palearctica (Paederus rubrothoracicus Goe., 1808, Lordithon trinitatus (Erich., 1839), Tachyporus hypnorum Fab., 1775). The representatives of the Omalium caesum Grav.1806 species are found in the northern part of the Palearctic. Emus hirtus L., 1758, Ocypus compressus (Marsh., 1802), Philonthus nitidus L., 1758, Xantholinus glabrathus Grav.1802, Olisthaerus substriathus (Payk., 1790) are characterized by belonging to the European type of habitat. The eurasian and European-Siberian types of habitat belong to Pseaphus heiser Olophrum rotundicolle (Sahl., 1830) species (Table 2). 


\section{CONCLUSIONS}

A group of beetles-predators habitats of the pine mountains is characterized by high species abundance. In the dominant structure, the Pycnoglypta lurida and Olophrum rotundicolle species prevail. In a spectrum of ecological-morphological groups, the representatives of a class of epibionts are the most numerous. Among the trophic groups, the most numerous are the predators. According to zoogeographical analysis, the biggtest number of species is characterized by the presence of the Holarctic type of range

1. Bey-Bienko G.Ya. The determinant of insects of the European part of the USSR in five volumes. Vol. 2. Higher School, 1965; 111-156. (In Russian)

2. Bogach Yu. A. Beetles-stafilins as bioindicators of ecological balance in the landscape, and human influence on the example of the city of Prague Bioindication in cities and suburban areas. Coll. scientific tr., 1993; 41-48.

3. Engelmann H.D. Zur Dominanzklassifizierung von Bodenartropoden. Pedobiologia, 1978; 5-6(18): 378-380.

4. Gorodkov C. B. Types of insect ranges of tundra and forest zones of the European part of the USSR. Areas of insects of the European part of the USSR, maps 179-221. Leningrad, Science,1984, p. 3-20.

5. Kascheev V.A. Classification of morphoecological types of imago staphilinids. Reports of the Academy of Sciences of the Kazakh SSR. Biological series, 1985; 1: 157-170. (In Russian)

6. Löbl I., Smetana A. Catalogue of Palaearctic Coleoptera. 2: Hydrophiloidea-Staphylinoidea. Stenstrup. Apollo Books: 2004, P. 942.

7. Magura T., Nagy D., Tóthmérész B. Rove beetles respond heterogeneously to urbanization. Journal of Insect Conservation, 2013: 17(4): 715-724.

[DOI: 10.1007/s10841-013-9555-y]

8. Mateleshko O. Yu. Faunistic records of the Staphylinidae (Coleoptera) from Transcarpathia. Visnyk of the Uzhgorod University. Series Biology, 2007; 21: 182-186. (In Ukrainian)

9. Örgel S., Anlas S. Faunistic studies on the subfamily Paederinae (Coleoptera: Staphylinidae) in Uşak Province, Western Anatolia. Acta Biologyca Turcica, 2016; 29(2): 61-66.

10. Petrenko A.A. Rove Beetles (Coleoptera, Staphylinidae) in the Red Book of Ukraine. Collection of scientific works (on the basis of reports of the scientific conference). 2005; 1 : 93-97. (In Ukrainian)

11. Petrenko A.A., Sheshurak P.M. Species composition of rove beetles (Cleoptera, Staphylinidae) of the national park "Desniansky-Starogutsky". Ukrainian Entomological Journal, 2013; 1(6): 50-64. (In Ukrainian)

12. Pietrykowska-Tudruj E., Staniec B. Comparative larval morphology of Platydracus and Staphylinus (Staphylinidae: Staphylinini: Staphylinina) with notes on their biology and redescription of the pupa of Staphylinus. Zootaxa, 2012; 24(42): 24-42.

[DOI: 10.11646/zootaxa.3580.1.2]

13. Sushko G. Species composition and zoogeography of the rove beetles (Coleoptera: Staphylinidae) of raised bogs of Belarus. North-Western Journal of Zoology, 2016; 12 (2): 220 229. (In Russian)

14. Yin, Zi-Wei, Joseph Parker, Chenyang Cai, Di-Ying Huang, Li-Zhen Li. A new stem bythinine in Cretaceous Burmese amber and early evolution of specialized predatory behaviour in pselaphine rove beetles (Coleoptera: Staphylinidae). Journal of Systematic Palaeontology, 2017; 2: 55-60.

[DOI: 10.1080/14772019.2017.1313790]

15. http://keys.lucidcentral.org/keys/v3/nastaphylinidae/

ISSN 1996-4536 (print) • ISSN 2311-0783 (on-line) • Біологічні Студії / Studia Biologica • 2019 • Том 13/№1 • C. 107-116 


\title{
ДО ВИВЧЕННЯ ЕКОЛОГІЧНОЇ ТА ЗООГЕОГРАФІЧНОЇ СТРУКТУРИ УГРУПОВАНЬ КОРОТКОНАДКРИЛИХ ЖУКІВ (STAPHYLINIDAE, COLEOPTERA, INSECTA) СУБАЛЬПІЙСЬКОГОГ ПОЯСУ ПІВНІЧНО-СХІДНОГО МАКРОСХИЛУ УКРАЇНСЬКИХ КАРПАТ
}

\author{
М. П. Луцька \\ Прикарпатський національний університет ім. В. Стефраника \\ вул. Галицька, 201, Івано-Франківськ 76000, Україна \\ e-mail: mariana.93.if@ukr.net
}

Проаналізовано екологічну та зоогеографрічну структуру коротконадкрилих жуків у біотопі криволісся Pinus mugo Turra, 1764 північно-східного макросхилу Українських Карпат. У результаті проведених досліджень у межах біотопу виявлено представників 24 видів, що належать до 19 родів і 10 підродин. Найвищий рівень видового багатства притаманний підродині Staphylininae (25\%). Ця підродина представлена родами Осурus (3 види) та Atrecus, Emus, Philonthus, Quedius - кожен із яких представлено особинами виду. Трохи менша кількість ідентифікованих видів притаманна підродині Таchyporinae - 5 видів, які належать до трьох родів: Lordithon (один вид), Tachinus (два види) Tachyporus (два види). Підродини Omaliinae та Oxytelinae представлені відповідно родами Pycnoglypta, Omalium, Olophrum та Oxytelus, Anotylus, Deleaster. Частка підродин, які характеризуються наявністю представників тільки одного виду, становить 50 \%. До цієї групи підродин належать: Oxyporinae, Paederinae, Pselaphinae, Steninae, Xantholininae, Olistaerinae.

Індекси Менхініка та Маргалефа є доволі високими (4,19 та 1,60 відповідно). Такий аспект вказує на незначну чисельність домінантних та еудомінантних видів. Показники індексу Сімпсона $(0,09)$ вказують на значне різноманіття субдомінантних і домінантних видів. Низькі показники індексу Паркера $(0,18)$ свідчать про незначну представленість найчисленнішого виду в аналізованому біотопі - Руспоglypta lurida (Gall., 1813). Угруповання Staphylinidae у межах біотопу сосни гірської характеризується наявністю представників чотирьох класів домінування (еудомінантів, домінантів, субдомінантів і рецедентів). Ядро досліджуваного угруповання формують представники груп еудомінантів і домінантів. До еудомінантів належать Deleaster dichrous Grav., 1892), Olophrum rotundicolle Sahlb., 1830, та Pycnoglypta Iurida Gyll., 1810. До групи домінантів належать Emus hirtus L., 1758, Tachinus elongatus Gyll., 1810. Групи субдомінантів і рецедентів характеризуються наявністю представників 13 та 6 видів відповідно. Унаслідок проведення аналізу екологічних і морфологічних груп було встановлено, що виявлені види належать до трьох класів: епібіонтів (58,34 \%), свердловинників $(28,14$ \%) і криптобіонтів $(12,51 \%)$. Переважна більшість виявлених видів за трофічною спеціалізацією $є$ хижаками (65 \%). Незначна частка видів належить до групи міксотрофрів, які поєднують у собі хижацтво з міцето- або сапрофагією. У результаті проведення зоогеографічного аналізу більшість виявлених видів належать до Голарктичної та Палеарктичної зоогеографрічних груп.

Ключові слова: Staphylinidae, екологічні та зоогеографрічні групи, життєві стратегії, Українські Карпати

Одержано: 18.03.2019

ISSN 1996-4536 (print) • ISSN 2311-0783 (on-line) • Біологічні Студії / Studia Biologica • 2019 • Том 13/№1 • С. 107-116 